\title{
Existence, Fate And Risk Assessment of Pharmaceuticals During Treatment of Domestic Wastewater: Mass Flow And Consumption Calculation
}

\author{
Mohamed I. Badawy \\ National Research Centre
}

Fatma A. El-Gohary

National Research Centre

Mahmoud S. Abdel-Wahed

National Research Centre

Tarek A. Gad-Allah

National Research Centre

Mohamed Eid Ali ( $\sim$ alienv81@yahoo.com )

National Research Centre, Egypt https://orcid.org/0000-0002-1157-1752

\section{Research Article}

Keywords: Pharmaceutical compounds, Mass balance, Occurrence, Wastewater, Wastewater treatment plants

Posted Date: September 3rd, 2021

DOl: https://doi.org/10.21203/rs.3.rs-810138/v1

License: (c) (i) This work is licensed under a Creative Commons Attribution 4.0 International License.

Read Full License 


\section{Abstract}

In Egypt, pharmaceuticals consumption is dramatically increasing, owing to the population growth and the unrestricted sale manner. Therefore, the occurrence and fate of nine pharmaceutical compounds (PhCs) were scrutinized at the different stages of sewage treatment plant (STP) in Giza, Egypt. Levels of these PhCs were assessed in wastewater and sludge phases by a high-performance liquid chromatography coupled. Nine PhCs were detected in both wastewater and sludge. Average concentration of the total PhCs detected in influent, primary sedimentation effluent and final effluent were 227, 155 and $89 \mu \mathrm{g} / \mathrm{L}$, respectively. The overall removal efficiency of the individual PhCs ranged from 18 $\%$ to $72 \%$ removal. The occurrence trend revealed that biodegradation and sorption are the concurrently removal mechanisms of the studied PhCs. As well, the calculated total mass load of individual PhCs were in the range $328-42256,152-26180$, and $257-6625 \mathrm{~g} \mathrm{~d}^{-1}$ for influent, effluent and sludge. Meanwhile, the calculated range of personal mass load of the individual PhCs was $193-15274$, $120-10864$ and $34-265 \mu \mathrm{g} \mathrm{d}^{-1} \mathrm{Pe}^{-1}$, for the influent, the final effluent and the sludge, respectively. The overall personal pharmaceutical consumption per day in West of Greater Cairo was estimated based on influent concentration of STP. Sulfamethoxazole, paracetamol and diclofenac were identified with the highest levels in the influent of STP, PSE and FE as well as in the dewatered sludge. Furthermore, the high concentrations of these compounds in the sludge confirms the sorption pathway removal of PhCs. Generally, the average daily and annual consumption per capita of the most dominant PhCs in wastewater; sulfamethazole, paracetamol and diclofenac are 60.09, 34.79, and $26.69 \mathrm{mg} \mathrm{d}^{-1} \mathrm{Pe}^{-1}$ and 22, 12.52 , and $12.52 \mathrm{~g} \mathrm{y}^{-1} \mathrm{Pe}^{-1}$, respectively. Moreover, risk assessment (RQ) for the detected PhCs in FE is greatly higher than the predicted non-effect concentration (PNEC). Conclusively, the FE of STP is considered a risky source for PhCs in adjacent surface water.

\section{Introduction}

Among the large number of molecules available, several compounds (antibiotics and anti-inflammatory drugs) are used in both human and veterinary medicine. In consequence of progressively repeated medication prescriptions and pharmaceuticals consuming, pharmaceutical contaminations and their byproducts have been identified in nearly all ecological parts (Bouissou-Schurtz, C., et al. 2014). Specifically, these emerging environmental contaminants have been detected globally in the discharge of municipal wastewater treatment plant (MWWTP) and water resources at small levels, ranging from ppt to $\mathrm{ppb}$ according to their stability, biodegradation, physical-chemical properties and efficacy of the MWWTP treatment (Andreozzi et al., 2002).

Unfortunately, the existing remediation technologies in sewage treatment plants (STPS) are designed to remove particulate matters, organic matters, dissolved organic carbon, as well as nitrogen and phosphorus, but not pharmaceutical compounds (Andreozzi et al., 2002). Accordingly, pharmaceuticals exist in sewage wastewater are not biologically destructed in STPs, and subsequently they are released to 
the surface water resources or sorbed onto the sludge and penetrate the soil reaching the groundwater sources upon using the sludge as fertilizer.

Lately, overpowering concern about the existence of $\mathrm{PhCs}$ as persistent pollutants in the environment is noticed due to their impending harmful effects on aquatic environment and earthly wildlife (Pomati et al., 2007; Martinez, 2008; Dirany et al., 2011). Significant fraction of original pharmaceuticals (PhCs) are released as unmetabolised or as byproducts, via urine and feces of human body or veterinary, and are discharged into the sewerage networks, which is the chief entrance pathway of PhCs. The existences of residual PhCs in STP effluents have been determined in different countries. The malfunction of STPs to eliminate the residual PhCs is endorsed to their undesirable impacts on microorganisms that responsible for the biological degradation of the organic materials (Gomez et al., 2007; 2007; Badawy et al., 2009). The attention for emerging contaminants existence has increased because of their harmful influences of non-target living organisms. The occurrence of antibiotics could results in developing bacteria with antibiotic resistance genes, thus, their occurrence and fate has a great concern of environmentalists. In addition, toxicity studies have highlighted the potential toxic effects of hospital effluents entering the aquatic environment (Hartmann et al., 1998; Emmanuel et al., 2004) and drug resistant bacteria have also been observed where hospital effluents are present (Jung et al., 2004; Caplin et al., 2007; Tuméo et al., 2008). Herein, the objectives of this work are to identify and quantify the levels of residual PhCs in the different stages of STP. The fate, mass balance and personal contribution for these pollutants have also been assessed.

\section{Material And Methods}

\subsection{Description of the study sites}

\subsubsection{Zenin Wastewater treatment plant (WWTP)}

Zenin WWTP is located in Giza at the west of Greater Cairo. The plant has a daily capacity of $400,000 \mathrm{~m}^{3}$ serving ca 2.5 million people. This municipal wastewater treatment plant includes a primary treatment step followed by an aerobic activated sludge for treating the combined wastewater as shown in Fig. 1 . The plant consists of three identical separate modules. The effluent wastewater is disposed into Nahia drainage and reaches Rosetta branch via El-Rahawy Drainage. Sludge treatment activity is performed at Zenin WWTP via thickening and drying into lagoons in the desert along Alexandria-Cairo Desert Road.

\subsection{Sampling and analysis}

Different composite wastewater samples were collected and stored in an ice-box, and then, transferred immediately to the laboratories of the Water Pollution Research Department for analysis. Two hundred and fifty millilitres of the sample was filtered using $0.45 \mu \mathrm{m}$ membrane filter. Prior application of the sample, $\mathrm{C}_{18}$ SPE cartridge (Phenomenex, Spain) was conditioned by adding $5 \mathrm{~mL}$ distilled water, then 5 $\mathrm{mL}$ methanol, and finally $5 \mathrm{~mL}$ distilled water. Adsorbed PhCs were eluted from the SPE cartridge by 
acetonitrile. Then, samples were evaporated to dryness and re-dissolved in $2 \mathrm{ml}$ methanol. Finally, $20 \mu \mathrm{l}$ of the extract was injected into a high performance liquid chromatography (HPLC). Analyses were carried out using Agilent 1260 HPLC (USA). The used analytical column was Zorbax SB-C18 (4.6 mm i.d. × 250 $\mathrm{mm}, 5 \mu \mathrm{m})$. Oven temperature was kept at $35^{\circ} \mathrm{C}$ during the analysis. Isocratic elution with a flow rate of 1 $\mathrm{mL} / \mathrm{min}$ was carried out using two eluents; Solution A was $0.017 \mathrm{M}$ phosphate buffer (40\%), while, solution B was acetonitrile (60\%).

\subsection{Mass balance analysis}

The average mass flow of each target compound was calculated as follow:

$M_{\text {aqueous }}(\mathrm{g} / \mathrm{d})=\mathrm{Q}_{\text {wastewater }} \times \mathrm{C}_{\text {aqueous }} \times 10^{-3}$ Eq. 1

$M_{\text {sludge }}(g / d)=Q_{\text {sludge }} \times C_{\text {sludge }}$ Eq. 2

where, $M_{\text {aqueous }}$ and $M_{\text {sludge }}\left(\mathrm{g} \mathrm{d}^{-1}\right)$ are the mass flows of the PhCs estimated in aqueous phase and sludge, respectively, $\mathrm{C}_{\text {aqueous }}\left(\mu \mathrm{g} \mathrm{L}^{-1}\right)$ and $\mathrm{C}_{\text {sludge }}\left(\mathrm{mg} \mathrm{kg}^{-1}\right)$ are the determined concentrations in the aqueous phase and sludge, respectively, and $Q_{\text {wastewater }}\left(m^{3} d^{-1}\right)$ and $Q_{\text {sludge }}\left(\right.$ ton $\left.d^{-1}\right)$ are the flow rates of wastewater and the production rate of sludge, respectively. Accordingly, the removal percentage of each compound $\left(\mathrm{R}_{\mathrm{i}} \%\right)$ from the effluents at the different treatment units can be calculated based on the following equation:

$\mathrm{R}_{\mathrm{i}} \%=M_{i} / M_{\text {influent }} \times 100$ influent Eq. 3

where, $M_{i}\left(g ~ d^{-1}\right)$ is the mass flow at the effluent of a certain PhCs, and $M_{\text {influent }}\left(\mathrm{g} \mathrm{d}^{-1}\right)$ is the mass flow at influent. The removal efficiency $(\mathrm{R} \%)$ of the investigated $\mathrm{PhCs}$ during the wastewater treatment was calculated based on Eq. 4:

$R \%=Q_{\text {wastewater }} \times C_{\text {effluent }} / Q_{\text {wastewater }} \times C_{\text {influent }}$ Eq. 4

where, $C_{\text {influent }}\left(\mu \mathrm{g} \mathrm{L}^{-1}\right)$, and $C_{\text {effluent }}\left(\mu \mathrm{g} \mathrm{L}^{-1}\right)$ are the measured concentrations in the influent, and the effluent, respectively.

\subsection{Calculation of pharmaceutical consumption}

In this study, the investigated STP was considered representative for the general situation in west of Greater Cairo because the plant treats over $30 \%$ of the municipal wastewater in Giza located in Greater Cairo. The daily use of PhCs was back-estimated based on their concentrations in the influent of the STP according to the following formula:

$$
U=\frac{C_{\text {influent }} \times Q_{\text {wastewatr }} \times 10^{-3}}{0.5}
$$


where, $\mathrm{U}$ represents the back-estimated usage of the target PhCs $\left(\mathrm{kg} \mathrm{year}^{-1}\right) ; \mathrm{C}_{\text {influent }}\left(\mu \mathrm{g} \mathrm{L}^{-1}\right)$ and $\mathrm{Q}\left(\mathrm{m}^{3}\right.$ $\mathrm{d}^{-1}$ ) refer to their previous definitions in Eqs. 4 and 5; 0.5 is a factor representing the ratio of the disposed drugs in wastewater to the drug sales.

\subsection{Environmental risk assessment}

The levels of each compound were compared to the acute and chronic quality standards proposed by the Swiss Ecotox Centre. The levels of pharmaceuticals in surface water and effluent were compared to the maximum allowable concentration (MAC), which corresponds to the acute quality standards, and to the annual average concentration (AAC), corresponding to the chronic quality standards. The chronic quality standard is particularly relevant to the assessment of the impact of long-term pollution on aquatic organisms. Furthermore, the potential risk of each pharmaceutical was assessed by calculating its risk quotient (RQ) defined as the ratio between the maximum measured environmental concentration and the predicted no-effect concentration (PNEC). PNEC is the concentration below which no adverse effects of exposure in an ecosystem are measured. It is calculated by applying an assessment factor (10 or 1000) on the lowest ecotoxicological values reported in the literature such as the no-observed-effect concentration (NOEC) or the concentration that causes adverse effects on $50 \%$ of the test organisms $\left(\mathrm{EC}_{50}\right)$, respectively, for the most sensitive species assayed.

\section{Results And Discussion}

\subsection{Occurrence and fate of PhCs through the treatment train of Zenin STP}

The average influent flow in the STP during the sampling periods was $400,000 \mathrm{~m}^{3} \mathrm{~d}^{-1}$. While after the treatment, the daily production of dried sludge was approximately 116 ton $^{-1}$. In this study, nine PhCs pollutants were analyzed in the influent (Inf), primary sedimentation effluent (PSE), final effluent (FE) of STP in west of Greater Cairo. The average concentrations of the studied individual PhCs in wastewater at the various stages of the treatment are summarized in Fig. 2. Sulfamethoxazole (85.36 and $105.64 \mathrm{\mu g} \mathrm{L}^{-}$ ${ }^{1}$ ), paracetamol (42.74 and $\left.65.45 \mu \mathrm{g} \mathrm{L}^{-1}\right)$, Diclofenac (26.48 and $\left.55.76 \mu \mathrm{g} \mathrm{L}^{-1}\right)$, and ampicillin (10.04 and $18.53 \mu \mathrm{g} \mathrm{L}^{-1}$ ) displayed the highest levels in the influent of STP. The analogue values for PhCs in PSE are sulfamethoxazole (58.34 and $82.28 \mu \mathrm{g} \mathrm{L}^{-1}$ ), paracetamol (36.72 and $45.12 \mu \mathrm{g} \mathrm{L}^{-1}$ ), diclofenac (17.91 and $38.28 \mu \mathrm{g} \mathrm{L}^{-1}$ ), and ampicillin (8.18 and $12.57 \mu \mathrm{g} \mathrm{L}^{-1}$ ). In FE of STP, the most dominant PhCs are sulfamethoxazole, paracetamol, diclofenac, and ampicillin, where the average levels of sulfamethoxazole, paracetamol, diclofenac, and ampicillin are amounted at 31.76, 24.68, 20.35, and 5.71 $\mu \mathrm{g} \mathrm{L}^{-1}$, respectively. The results revealed that sulfamethoxazole, and diclofenac are much higher than that previously investigated in WWTPs in China (Yan, 2014) and France (Chiffre et al., 2016; .Thiebault et al., 2017). The of diclofenac, paracetemol and sulfamethazole showed higher levels is dewatered sludge that is higher than that previously reported in other regions (Chiffre et al., 2016; .Thiebault et al., 2017). 


\subsection{Dominance and Removal pathway of PhCs pollutants through the treatment train of Zenin STP}

Figure 2 depicts the distribution trends of PhCs in the different stages of STP; Influent, PSE, FE and sludge. The studied antibiotics (Fig. 2a) pattern indicates that sulfamethazole dominance represented $79.5 \%$ of the total antibiotics amount in the Influent, $82.4 \%$ in the PSE and $77.6 \%$ in the FE; while, it amounted by $59 \%$ in the sludge. The trend of anti-inflammatory PhCs in Fig. 1b showed the following order paracetamol > diclofenac > > acetylsalicylic acid. This indicates the higher consumption pattern of sulfamethazole, paracetamol and diclofenac as medications. The presence trends of the target PhCs indicates their participation into different stream STP and reflect the usage pattern of PhCs in the service area to a definite level.

Additionally, different removal pathways of PhCs were assessed. Variations in the removal \% of pharmaceutical compounds in STP are presented in Fig. 2. It was found that adsorption and biodegradation are the concurrent removal mechanisms of most of the studied PhCs. Additionally, the results reveal that acetylsalicylic acid was removed in particular via adsorption on the particulate matter of sludge with an efficiency reaching $70 \%$. The other anti-inflammatory PhCs were removed via the assisted removal mechanisms. The recorded adsorption and biodegradation rates were $33 \%$ and $26 \%$ for diclofenac, and 41.66 and $24.68 \%$ for paracetamol, respectively, revealing their lower removing by biodegradation process. These findings are inconsistence with previous data (Verlicchi et al., 2012; Thiebault et al., 2017). Removal rate of studied the antibiotics via adsorption ranged from lower (18\%) to moderate value (43\%). Meanwhile, biodegradation rate of the studied antibiotics varied from 24 to $58 \%$, indicating moderate biodegradation transformation of antibiotic by activated sludge bacteria.

\subsection{Mass balance of PhCs in the different stages of STP}

Mass flow and mass balance of the individual PhCs were performed to evaluate their potential removal mechanisms in the STP (Fig. 3). The influent mass load for all target PhCs was $90,616 \mathrm{~g} \mathrm{~d}^{-1}$. Mass loads for PSE and final effluent of all studied PhCs were $61,976 \mathrm{~g} \mathrm{~d}^{-1}$ and $35,748 \mathrm{~g} \mathrm{~d}^{-1}$, respectively. The mass loads of the individual PhCs varied from 484 to $38,184 \mathrm{~g} \mathrm{~d}^{-1}$ for aspramycin and sulfametazole, respectively, in the influent and from 184 to 12,704 in the final effluent of STP. The adsorbed amounts were remarkable. The total mass load of the selected PhCs in the dewatered sludge (without further digestion) was 20,193 $\mathrm{g} \mathrm{d}^{-1}$. Diclofenac and paracetamol were the predominant residual $\mathrm{PhCs}$ in the dried sludge. Figure 5 showed the personal load for different PhCs, the results showed the same of mass balance. The personal median mass load $\left(\mathrm{C}_{\mathrm{pe}}, \times 10^{3} \mathrm{\mu g} \mathrm{d}^{-1} \mathrm{Pe}^{-1}\right)$ of the individual PhCs was estimated according to multiplying the concentration in the sewage $\left(\mathrm{Ci}, \mu \mathrm{g} \mathrm{L}^{-1}\right)$ and the average treated flow rate $(\mathrm{Q}$, $\mathrm{m}^{3} \cdot \mathrm{d}^{-1}$ ) during the sampling period and normalizing this value to the population served by the corresponding WWTP. The equation is expressed as following;

$C_{p e}=C_{\text {inf }} \times Q$ /served population number Eq. 5 
The median values are shown in Fig. 5. The mass load of the target PhCs in influent revealed the input into WWTP and indicated the use pattern of PhCs in the served region to a definite magnitude. By contrast, the PhCs mass load in effluent is used to estimating the risk of PhCs to the water resources. The total average personal mass flow for studied PhCs was found to be $70.2 \times 10^{3} \mu \mathrm{g} \mathrm{d}^{-1} \mathrm{Pe}^{-1}$ and $51.83 \mathrm{x}$ $10^{3} \mathrm{\mu g} \mathrm{d}^{-1} \mathrm{Pe}^{-1}$ for influent of WTP and effluent to the receiving water. The daily mass flow per person

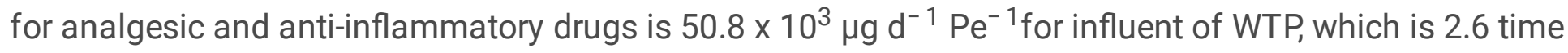
higher that daily mass flow per person of total antibiotic (i.e. $19.3 \times 10^{3} \mathrm{\mu g} \mathrm{d}^{-1} \mathrm{Pe}^{-1}$ ) which shall be endorsed to the fame and common use of these drugs. However, daily flow mass per capita was detected in the current served region is many times higher than that detected in Spain $\left(7485 \mathrm{~d}^{-1} \mathrm{Pe}^{-1}\right)$, the United States $\left(15440 \mu \mathrm{g} \mathrm{d}^{-1} \mathrm{Pe}^{-1}\right)$, China $\left(4950 \mu \mathrm{g} \mathrm{d}^{-1} \mathrm{Pe}^{-1}\right)$ and France $\left(4774.7 \mu \mathrm{g} \mathrm{d}^{-1} \mathrm{Pe}^{-1}\right)$ (Karthikeyan and Meyer, 2006; Gracia-Lor et al., 2012; Yan et al., 2014, Thiebault et al., 2017). Meanwhile, the calculated daily personal mass flow of analgesics and anti-inflammatory drugs and antibiotics into the receiving water are $36.79 \times 10^{3} \mathrm{\mu g} \mathrm{d}^{-1} \mathrm{Pe}^{-1}$ and $14.04 \times 10^{3} \mathrm{gg} \mathrm{d}^{-1} \mathrm{Pe}^{-1}$, respectively. These discharged levels are much higher than those detected in other regions (Karthikeyan and Meyer, 2006; Gracia-Lor et al., 2012; Yan et al., 2014, Thiebault et al., 2017). The mass flow levels of two other analgesics, namely, paracetamol and diclofenac are found to be 8690 and $6670 \mu \mathrm{g} \mathrm{d}^{-1} \mathrm{Pe}^{-1}$ in influent, respectively. These values are many times higher than those determined in industrialized countries such as USA (IBP: 8257 $\mu \mathrm{g} \mathrm{d}^{-1} \mathrm{Pe}^{-1}$; DCF: $103 \mu \mathrm{g} \mathrm{d}^{-1} \mathrm{Pe}^{-1}$ ) (Yu et al., 2013), Sweden (IBP: $920 \mu \mathrm{g} \mathrm{d}^{-1} \mathrm{Pe}^{-1}$; DCF: $31 \mu \mathrm{g} \mathrm{d}^{-1} \mathrm{Pe}^{-}$ ${ }^{1}$ ) (Zorita et al., 2009), Spain (IBP: $1983 \mu \mathrm{g} \mathrm{d}^{-1} \mathrm{Pe}^{-1}$; DCF: $72 \mu \mathrm{g} \mathrm{d}^{-1} \mathrm{Pe}^{-1}$ ) (Gracia-Lor et al., 2012), and Greece (IBP: $165 \mu \mathrm{g} \mathrm{d}^{-1} \mathrm{Pe}^{-1}$; DCF: $311 \mu \mathrm{g} \mathrm{d}^{-1} \mathrm{Pe}^{-1}$ ). As well the mass flow levels of common antibiotics, namely, sulfamethazole and ampicillin are found to be 15280 and $2198.4 \mu \mathrm{g} \mathrm{d}^{-1} \mathrm{Pe}^{-1}$ in influent, respectively that are higher in comparable with previously investigated in other regions (Lindberg et al., 2005; Castiglioni et al., 2006; Watkinson et al., 2007; Gracia-Lor et al., 2012). Sulfamethazole, diclofenac and paracetamol had the highest average daily mass load per person in effluent as shown in Fig. 5. To our knowledge, the calculated daily mass load per person for aspramycin, lincomycin, streptomycin and chloramphenicol have not been previously investigated in other countries in WWTP steams. Finally, the PhCs detected in the current study were compared with the available data in literature as presented in Table 1. The PhCs concentrations detected in this study is slightly higher that alerts the possible environmental threat by these compounds.

Table 1 Global Comparison for pharmaceutical compound levels with current study 


\begin{tabular}{|c|c|c|c|}
\hline PhCs & $\begin{array}{l}\text { PhCs levels in influent } \\
\text { (ng/ L) }\end{array}$ & $\begin{array}{l}\text { PhCs levels in Effluent } \\
(\mathrm{ng} / \mathrm{L})\end{array}$ & Ref. \\
\hline sulfamethoxazole & - & $<1000$ & (Barber et al. 2013) \\
\hline Sulfapyridine & 251.7 & 99.9 & \multirow{10}{*}{$\begin{array}{l}\text { (Semerjian et al. } \\
\text { 2018) }\end{array}$} \\
\hline Sulfamethazine & 23.7 & 11.0 & \\
\hline Sulfadiazine & 720.2 & 433.4 & \\
\hline Sulfamethoxazole & 161.8 & 75.1 & \\
\hline Ciprofloxacin & 862.7 & 543.4 & \\
\hline Ofloxacin & 845.9 & 510.8 & \\
\hline Erythromycin & 785.2 & 541.2 & \\
\hline Acetaminophen & $145,250.3$ & 5235.3 & \\
\hline Metoprolol & 92.1 & 62.5 & \\
\hline Risperidone & 244.8 & 13.2 & \\
\hline Diclofenac & - & $965-2476$ & \multirow[t]{3}{*}{ (Chiffre et al. 2016) } \\
\hline Sulfamethoxazole & - & $655-1380$ & \\
\hline carbamazepine & - & $566-1007$ & \\
\hline Sulfadiazine & $202.8-257.8$ & $117.8-174.8$ & \multirow[t]{14}{*}{ (Yan et al. 2014) } \\
\hline sulfamethazine & $129-174.4$ & $31.7-47.2$ & \\
\hline Sulfamethoxazole & $2460.4-3180$ & $1060.3-1212.2$ & \\
\hline Trimethoprim & $51.9-98.8$ & $37.9-75.5$ & \\
\hline Ofloxacin & $276.7-401.5$ & $43.0-82.9$ & \\
\hline Norfloxacin & $186.3-225.1$ & $25.5-34.2$ & \\
\hline Moxifloxacin & 27.6 & $5.7-7.7$ & \\
\hline Erythromycin & $238.6-275.4$ & $135.9-174.0$ & \\
\hline Roxithromycin & $359.7-434.6$ & $300.6-386.4$ & \\
\hline Azithromycin & $330.27-376.5$ & $58-111.0$ & \\
\hline Ibuprofen & $243.8-296.5$ & $11.9-16.3$ & \\
\hline Diclofenac & 6.01 & $2.9-3.7$ & \\
\hline Acetaminophen & $6813.5-7515.6$ & 10 & \\
\hline Bezafibrate & $98.75-140.13$ & $50.2-92.3$ & \\
\hline
\end{tabular}




\begin{tabular}{|c|c|c|}
\hline Clofibric acid & $17.5-47.9$ & $15.4-17.1$ \\
\hline Gemfibrozil & $12.7-18.2$ & $2.7-3.4$ \\
\hline Metoprolol & $43.18-54.1$ & $51.1-82.5$ \\
\hline Amlodipine & - & $4.6-5.3$ \\
\hline atorvastatin & $1.0-1.9$ & 0.6 \\
\hline simvastatin & $101.4-133.7$ & 30.2 \\
\hline Carbamazepine & $9.8-20.1$ & $13.6-21.0$ \\
\hline Acetaminophen & $22600-96700$ & 13- 172 \\
\hline Atenolol & $3560-26500$ & 893-9320 \\
\hline Carbamazepine & $51-937$ & $5-357$ \\
\hline Codeine & $270-2110$ & 137- 518 \\
\hline Diazepam & 420 & 30 \\
\hline Doxepin & $92-1020$ & 28- 299 \\
\hline Gemfibrozil & 648 & 105 \\
\hline Ketoprofen & $149-6560$ & $10-176$ \\
\hline Metoprolol & $277-2760$ & $121-1750$ \\
\hline Naproxen & $457-4740$ & $58-238$ \\
\hline Oxazepam & $154-2020$ & $5-1130$ \\
\hline Salicylic acid & $2360-25500$ & $7-423$ \\
\hline Tramadol & $1350-9860$ & $72-1190$ \\
\hline Diclofenac & $63-1190$ & $43-1380$ \\
\hline Ibuprofen & $1560-7280$ & $6-284$ \\
\hline Sulfamethoxazole & $85360-105640$ & 31760 \\
\hline Paracetamol & $42740-65450$ & 24680 \\
\hline Diclofenac & $26480-55760$ & 20350 \\
\hline ampicillin & $10040-18530$ & 5710 \\
\hline
\end{tabular}

(Thiebault et al. 2017)
This work

\subsection{Consumption assessment}

Based on the existed level of selected PhCs and their pharmokinetics, the estimated calculation of the daily and annual personal consumption in the studied region is shown in Table 2. These values were 
compared with previously reported data in China (Yan et al., 2014), Spain (Ortiz De Carcia et al., 2013; Carballa et al., 2008), Netherland (Oosterhuis et al., 2013), Switerland (Ter Laak et al., 2010; Gobel et al., 2005), Germany (Alder et al., 2006), Poland (Carballa et al. 2008). Sulfamethazole, and diclofenac show an annual personal consumption higher that recorded in abovementioned regions. Meanwhile, paracetemol consumption showed lower consumption than that reported in China $\left(11.82 \mathrm{~g} \mathrm{y}^{-1} \mathrm{Pe}^{-1}\right)$ (Yan et al., 2014), Spain (31.05 $\mathrm{g} \mathrm{y}^{-1} \mathrm{Pe}^{-1}$ ) (Ortiz De Carcia et al., 2013).

Table 2 Predicated back-estimated consumption of studied PhCs in the studied region

\begin{tabular}{|lll|}
\hline PhCs & $\begin{array}{l}\text { Average personal consumption }(\mathrm{mg} \\
\left.\mathrm{d}^{-1} \mathrm{Pe}^{-1}\right)\end{array}$ & $\begin{array}{l}\text { Estimated annual consumption }(\mathrm{g} \\
\left.\mathrm{y}^{-1} \mathrm{Pe}^{-1}\right)\end{array}$ \\
\hline Aspramycin & 0.77 & 0.277 \\
\hline Ampillicin & 8.79 & 3.16 \\
\hline Lincomycin & 0.57 & 2.05 \\
\hline Chloroamphenicol & 4.58 & 1.66 \\
\hline Streptomycin & 1.04 & 0.374 \\
\hline Sulfamethaxozole & 61.09 & 22 \\
\hline $\begin{array}{l}\text { Acetylsalicylic } \\
\text { acid }\end{array}$ & 6.66 & 2.4 \\
\hline Diclofenac & 26.69 & 9.61 \\
\hline Paracetamol & 34.79 & 12.52 \\
\hline
\end{tabular}

\section{5. Risk quotient (RQ) of the final effluent}

Risk quotient (RQ), which is the ratio between the measured concentration of each compound and their corresponding PNEC (predicted no-effect concentration), was assessed for the final effluent to estimate the ecotoxicological potential of the studied nine PhCs in the wastewater discharged from the STP. RQ of FE for receiving water showed that ampillicin, chloroamphenicol, diclofenac, paracetamol and sulfamethoxazole were the most critical compounds and posed a medium and high environmental risk $(R Q>0.1$ and $R Q>1)$, respectively. Up to now, European and French legislation has not provided limits for the concentrations of PhCs in STP effluent. However, comparing the levels of PhCs in effluent showed that the above mentioned compounds surpass the long-term quality standard recommended by the Swiss Ecotox Centre (www.centre ecotox.ch). Furthermore, we estimated the toxicity level of effluents using RQ value. The data showed that FE of STP has a higher risk to receiving water due to high values of RQ for ampicillin, sulfamethazole and diclofenac. Other selected PhCs showed lower and non-risky value of RQ to receiving water. 


\section{Conclusion}

In this work, the levels of nine PhCs contaminants were analysed through the wastewater treatment train of Zenin sewage treatment plant. It is worth mentioning that paracetemol, sulfamethazole and diclofenac showed relatively high concentrations in STP influent and effluent. The most dominant PhCs in STP effluent were diclofenac, paracetemol, acetylsalicylic acid sulfamethazole and ampicillin. Tracing the concentration of the PhCs at each treatment stage revealed that both adsorption and biodegradation are the removal mechanisms. Finally, it was found that WWTP represent a major source for discharge of PhCs to the environment. However, diclofenac, ampillicin, and sulfamethazole show risk quotient ten times higher than their corresponding PNEC values. The levels of aspramycin, streptomycin, and Lincomycin recorded the lower $\mathrm{RQ}$ to receiving water.

\section{Declarations}

\section{Acknowledgements}

The authors thank the the Science and Technology Development Fund (STDF) for the logistical help and for funding this work through a STDF funded Grand project entitled "Imperative Technologies for Hospital Wastewater Treatment".

\section{Ethical approval and consent to participate}

Not applicable.

\section{Consent to publish}

Not applicable.

\section{Conflict of interest}

The authors declare that they have no competing interests.

\section{Authors Contributions}

Mohamed I. Badawy: Conceptualization, Supervision

Fatma A. El-Gohary: Funding acquisition, Supervision

Mahmoud S. Abdel-Wahed: Investigation

Tarek A. Gad-Allah: Investigation, Visualization

Mohamed E.M. Ali: Investigation, Visualization, Writing - original draft, Writing - review \& editing 


\section{References}

1. APHA, AWWA (2009) Standard Methods for the Examination of Water and Wastewater, 22. WPCF, New York

2. Axelle Chiffre F, Degiorgi A, Buleté L, Spinner P-M, Badot (2016) Occurrence of pharmaceuticals in WWTP effluents and their impact in a karstic rural catchment of Eastern France. Environ Sci Pollut Res 23:25427-25441

3. Badawy MI, Wahaab RA, El-Kalliny AS (2009) Fenton-Biological Treatment Processes for the Removal of Some Pharmaceuticals from Industrial Wastewater. J Haz Mat 167:567-574

4. Barber LB, Keefe SH, Brown GK, Furlong ET, Gray JL, Kolpin DW, Meyer MT, Sandstrom MW, Zaugg SD (2013) Persistence and potential effects of complex organic contaminant mixtures in wastewater-impacted streams. Environ Sci Technol 47(5):2177-2188

5. Beate I, Escher R, Baumgartner M, Koller K, Treyer J, Lienert, Christa S (2011) McArdell Environmental toxicology and risk assessment of pharmaceuticals from hospital wastewater. Water Res 45:75-92

6. Bendz D, Pax́eus NA, Ginn TR, Loge F (2005) Occurrence and fate of pharmaceutically active compounds in the environment, a case study: Höje River in Sweden. J Hazard Mater 122:195-204

7. Bertanza G, Collivignarell C, Pedrazzen IR (2001) The role of chemical oxidation in combined chemical-physical and biological processes: experience of industrial wastewater treatment. Water Sci Technol 44:109-116

8. Caplin JL, Hanlon GW, Taylor HD (2008) Presence of vancomycin and ampicillin-resistant Enterococcus faecium of epidemic clonal complex-17 in wastewaters from the south coast of England. Environ Microbiol 10(4):885-892

9. Carballa M, Omil F, Lema JM (2008) Comparison of predicted and measured concentrations of selected pharmaceuticals, fragrances and hormones in Spanish sewage. Chemosphere 72:11181123

10. Carballa M, Omil F, Lema JM, Llompart M, García-Jares C (2004) and Rodríguez I. Behaviour of pharmaceuticals, cosmetics and hormones in a sewage treatment plant. Water Res 38:2918-2926

11. Castiglioni S, Bagnati R, Fanelli R, Pomati F, Calamari D, Zuccato E (2006) Removal of pharmaceuticals in sewage treatment plants in Italy. Environmental Science Technology 40:357-363

12. Chiffre A, Degiorgi F, Buleté A, Spinner L, Badot P-M (2016) Occurrence of pharmaceuticals in WWTP effluents and their impact in a karstic rural catchment of Eastern France. Environl Sci Pollution Research 23(24):25427-25441

13. Emmanuel E, Perrodin Y, Keck G, Blanchard JM, Vermande P (2005) Ecotoxicological risk assessment of hospital wastewater: A proposed framework for raw effluents discharging into urban sewer network. J Haz Mat 117A:1-11 
14. Ferrari B, Paxéus N, Giudice L, Pollio R, A. and Garric J (2003) Ecotoxicological impact of pharmaceuticals found in treated wastewaters: study of carbamazepine, clofibric acid, and diclofenac. Ecotoxicol Environ Safety 55:359-370

15. Gagné $F$, Blaise $C$, André $C$ (2006) Occurrence of pharmaceutical products in a municipal effluent and toxicity to rainbow trout (Oncorhynchus mykiss) hepatocytes. Ecotoxicol Environ Safety 64:329-336

16. Gobel A, Thomsen A, McArdell CS, Joss A, Giger W (2005) Occurrence and sorption behavior of sulfonamides, macrolides, and trimethoprim in activated sludge treatment, 39. Environmental Science \& Technology, pp 3981-3989

17. Gómez MJ, Martínez Bueno MJ, Lacorte S, Fernández-Alba AR, Agüera (2007) Pilot survey monitoring pharmaceuticals and related compounds in a sewage treatment plant located on the Mediterranean coast. Chemosphere 66:993-102

18. Gracia-Lor E, Sancho JV, Serrano R, Hernandez F (2012) Occurrence and removal of pharmaceuticals in wastewater treatment plants at the Spanish Mediterranean area of Valencia. Chemosphere 87:453-462

19. Hartmann A, Alder AC, Koller T, Widmer R (1998) Identification of fluorochinolone antibiotics as the main source of amuC genotoxicity in native hospital waste water. Environ Toxicol Chem 17:383-393

20. Jung R, Fish DN, Obritsch MD, MacLaren R (2004) Surveillance of multi-drug resistant Pseudomonas aeruginosa in an urban tertiary-care teaching hospital. J Hos Inf 57:105-111

21. Kümmerer K (2009) the presence of pharmaceuticals in the environment due to human use - present knowledge and future challenges. J Environ Manag 90:2354-2366

22. Kümmerer K (2001) Drugs in the environment: emission of drugs, diagnostic aids and disinfectants into wastewater by hospitals in relation to other sources-a review. Chemosphere 45:957-969

23. Larsson DGJ, de Pedro C, Paxeus N (2007) Effluent from drug manufactures contains extremely high levels of pharmaceuticals Effluent from drug manufactures contains extremely high levels of pharmaceuticals. J Hazard Mater 148:751-755

24. Lindberg RH, Wennberg P, Johansson MI, Tysklind M, Andersson BA (2005) Screening of human antibiotic substances and determination of weekly mass flows in five sewage treatment plants in Sweden. Environmental Science Technology 39:3421-3429

25. Lindqvist $\mathrm{N}$, Tuhkanen $\mathrm{T}$, Kronberg $\mathrm{L}$ (2005) Occurrence of acidic pharmaceuticals in raw and treated sewages and in receiving waters. Water Res 39:2219-2228

26. Nikolaou A, Meric S, Fatta D (2007) Occurrence patterns of pharmaceuticals in water and wastewater environments. Anal Bioanal Chem 387:1225-1234

27. Oosterhuis M, Sacher F, Laak T (2013) T.L.,. Prediction of concentration levels of metformin and other high consumption pharmaceuticals in wastewater and regional surface water based on sales data. The Science of the Total Environment 442:380-388

28. Ortiz de Garcia, S, Pinto Pinto G, Garcia Encina P, Irusta Mata R (2013) Consumption and occurrence of pharmaceutical and personal care products in the aquatic environment in Spain. The Science of the Total Environment 444:451-465 
29. Verlicchi P, Al Aukidy M, Zambello E, Occurrence of pharmaceutical compounds in urban wastewater: removal, mass load and environmental risk after a secondary treatment-a review, Sci Total Environ. 2012; 429 123-155, http://dx.doi.org/ 10.1016/j.scitotenv.2012.04.028

30. Qing Y, Gao Xu, Huang L, Gan X-M, Zhang Y-X, You-Peng Chen a,d, Peng X-Y, Jin-Song Guo. Occurrence and fate of pharmaceutically active compounds in the largest municipal wastewater treatment plant in Southwest China: Mass balance analysis and consumption back-calculated model, Chemosphere 2014; 99 160-170

31. Robinson AA, Belden JB, Lydy MJ (2005) Toxicity of fluoroquinolone antibiotics to aquatic organisms. Environ Toxicol Chem 24:423-443

32. Semerjian L, Shanableh A, Semreen MH, Samarai M (2018) Human health risk assessment of pharmaceuticals in treated wastewater reused for non-potable applications in Sharjah, United Arab Emirates. Environment international 121:325-331

33. ter Laak TL, van der Aa M, Houtman CJ, Stoks PG, van Wezel AP,. Relating environmental concentrations of pharmaceuticals to consumption: a mass balance approach for the river Rhine. Environment International 201036, 403-409

34. Ternes T (1998) Occurrence of drugs in German sewage treatment plants and rivers. Science Technology 40:357-363

35. Thiebault T, Boussafir M, Le Milbeau C (2017) Occurrence and removal efficiency of pharmaceuticals in an urban wastewater treatment plant: Mass balance, fate and consumption assessment. Journal of environmental chemical engineering 5(3):2894-2902

36. Tuméo E, Gbaguidi-Haore H, Patry I, Bertrand X, Thouverez M, Talon D (2008) Are antibiotic resistant Pseudomonas aeruginosa isolated from hospitalised patients recovered in the hospital effluents? Int J Hyg Environ Health 211:200-204

37. USFDA (1998) Guidance for Industry; Environmental Assessment of Human Drugs and Biologics Application, US Food and Drug Administration,

38. Yan Q, Gao X, Huang L, Gan X-M, Zhang Y-X, Chen Y-P, Peng X-Y, Guo J-S (2014) Occurrence and fate of pharmaceutically active compounds in the largest municipal wastewater treatment plant in Southwest China: mass balance analysis and consumption back-calculated model. Chemosphere 99:160-170

\section{Figures}




$\begin{array}{ccccc} & \text { Grit/sand } & \text { Activated } & \text { Secondary } \\ \text { Removing } & \text { Primary } & \text { Sludge } & \text { Clarifier } \\ \text { Screening } & \text { Chamber } & \text { Clarifier } & \text { Reactor } & \end{array}$

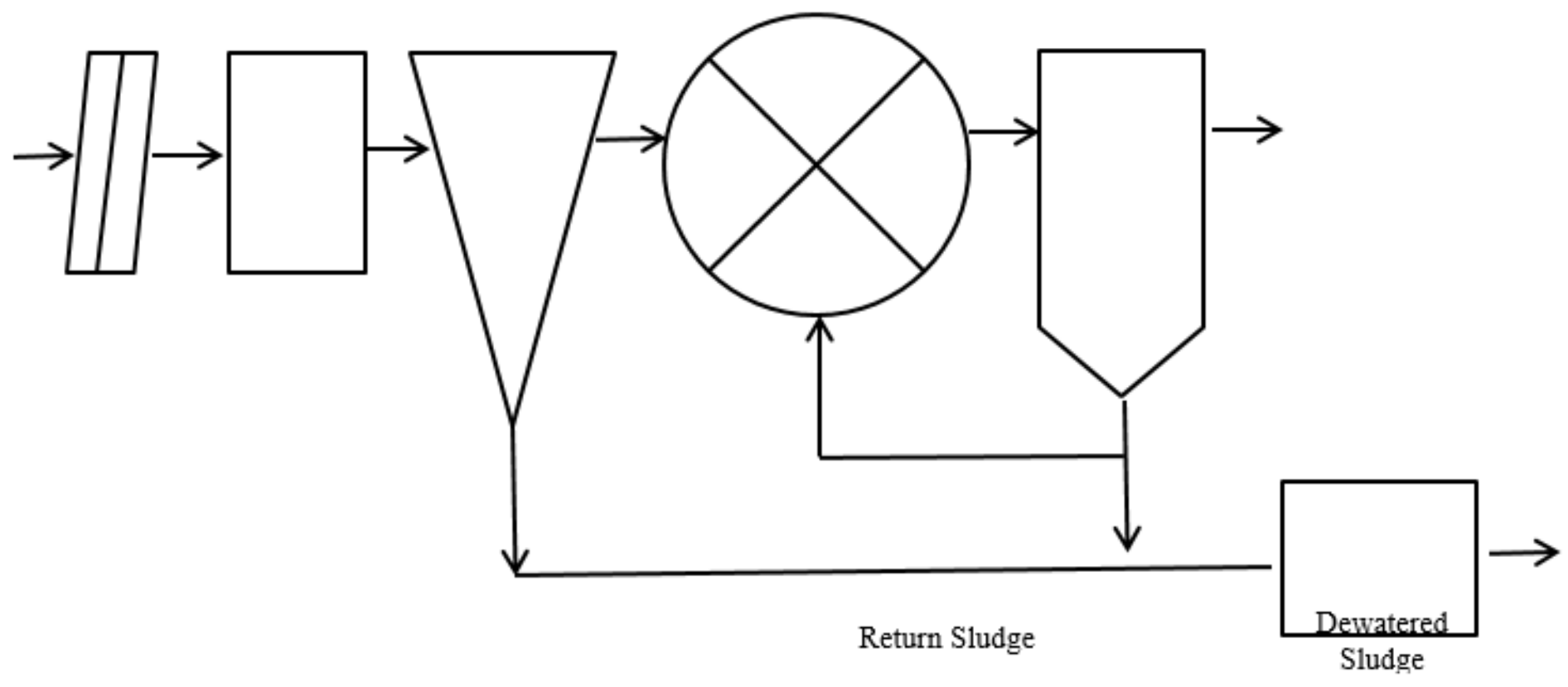

Excess Sludge

Figure 1

Process flow diagram for Zenin WWTP in Giza, Egypt 


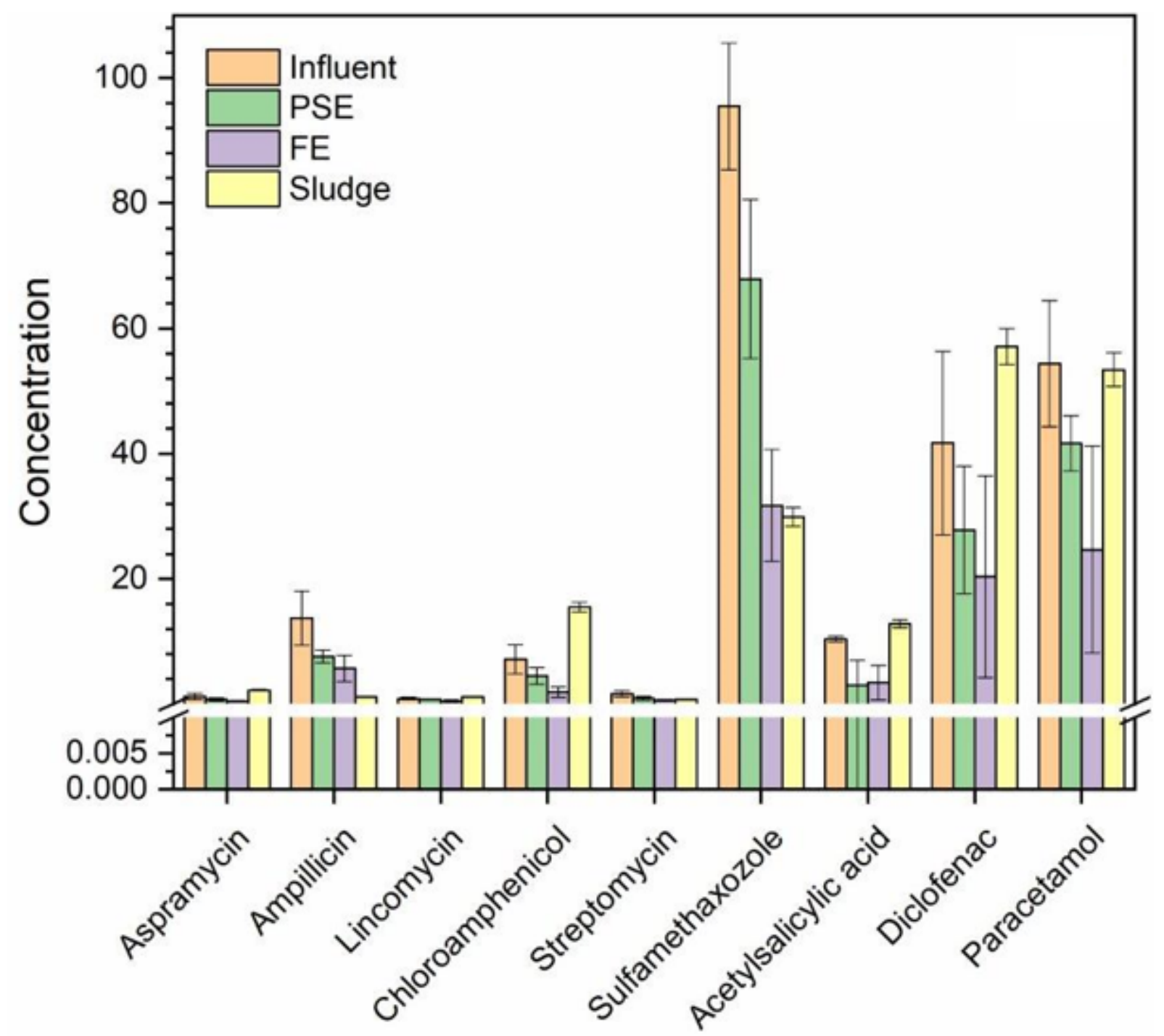

Figure 2

Existence of different PhCs in the wastewater samples during different stages of Zenin STP and distribution of PhCs in sludge (i.e. Concentration unit for liquid phase $\mu \mathrm{L} L-1$, Concentration unit for sludge $\mathrm{mg} \mathrm{kg}-1$ ) 

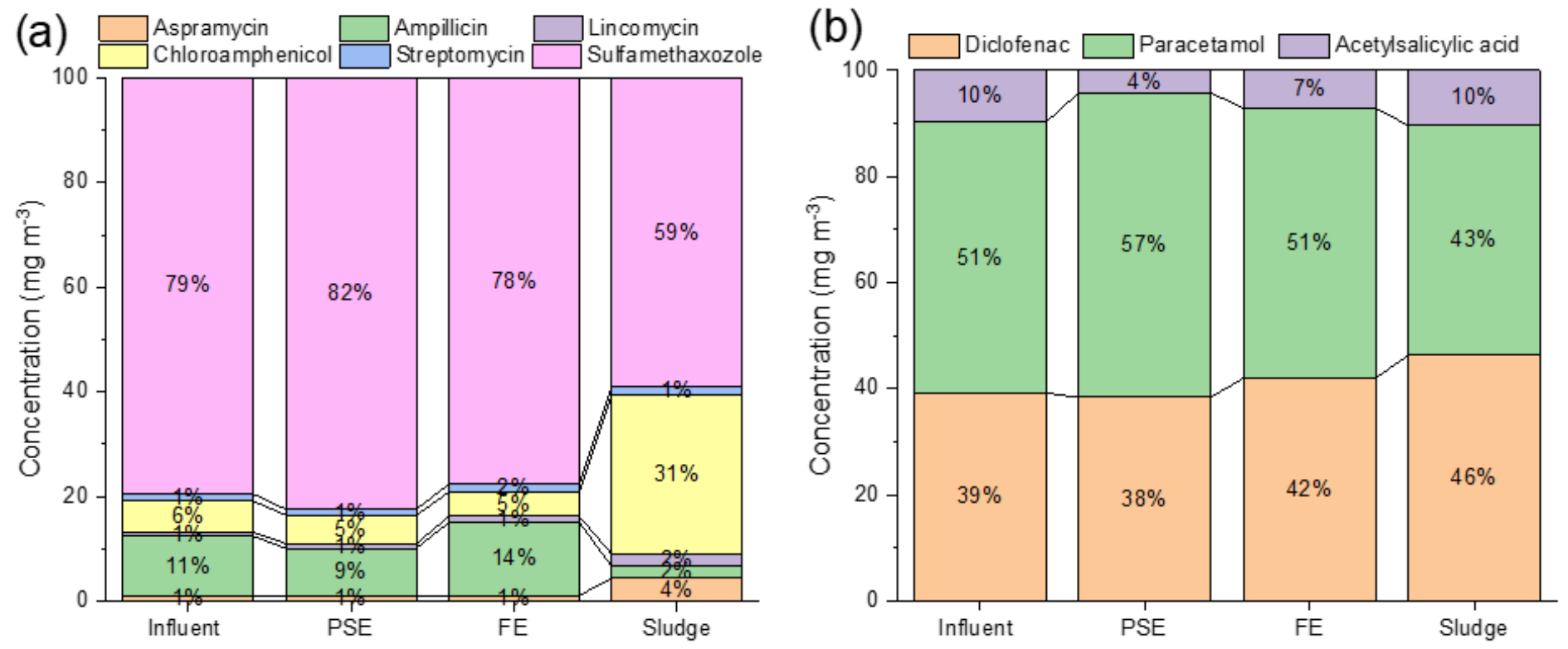

Figure 3

Distribution pattern of Pharmaceutical compounds in different stages of STP Sorption $\square$ Biodegradation $\square$ Total

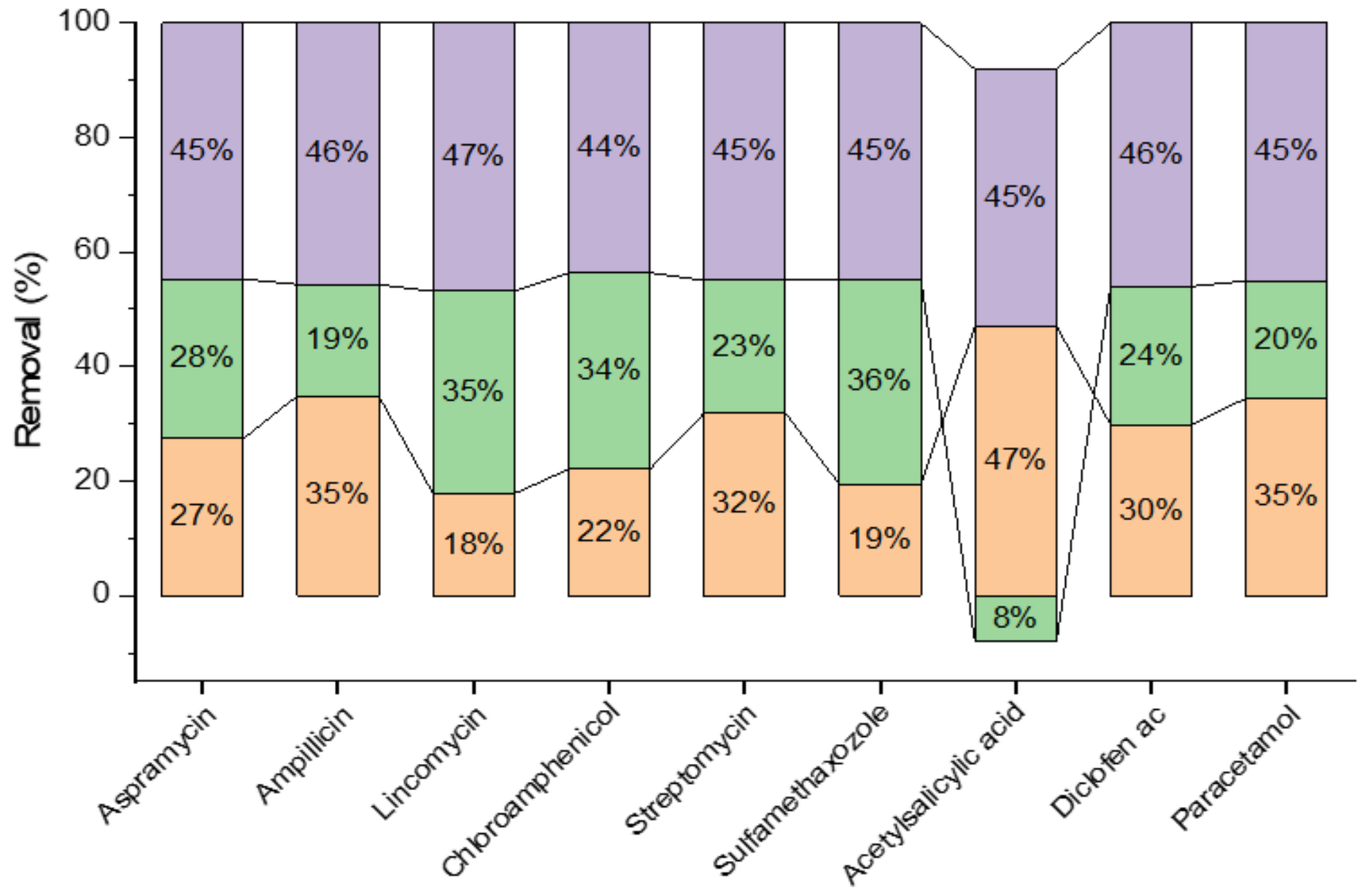

Figure 4 
Removal percentages of pharmaceutical compounds in different stages of STP.

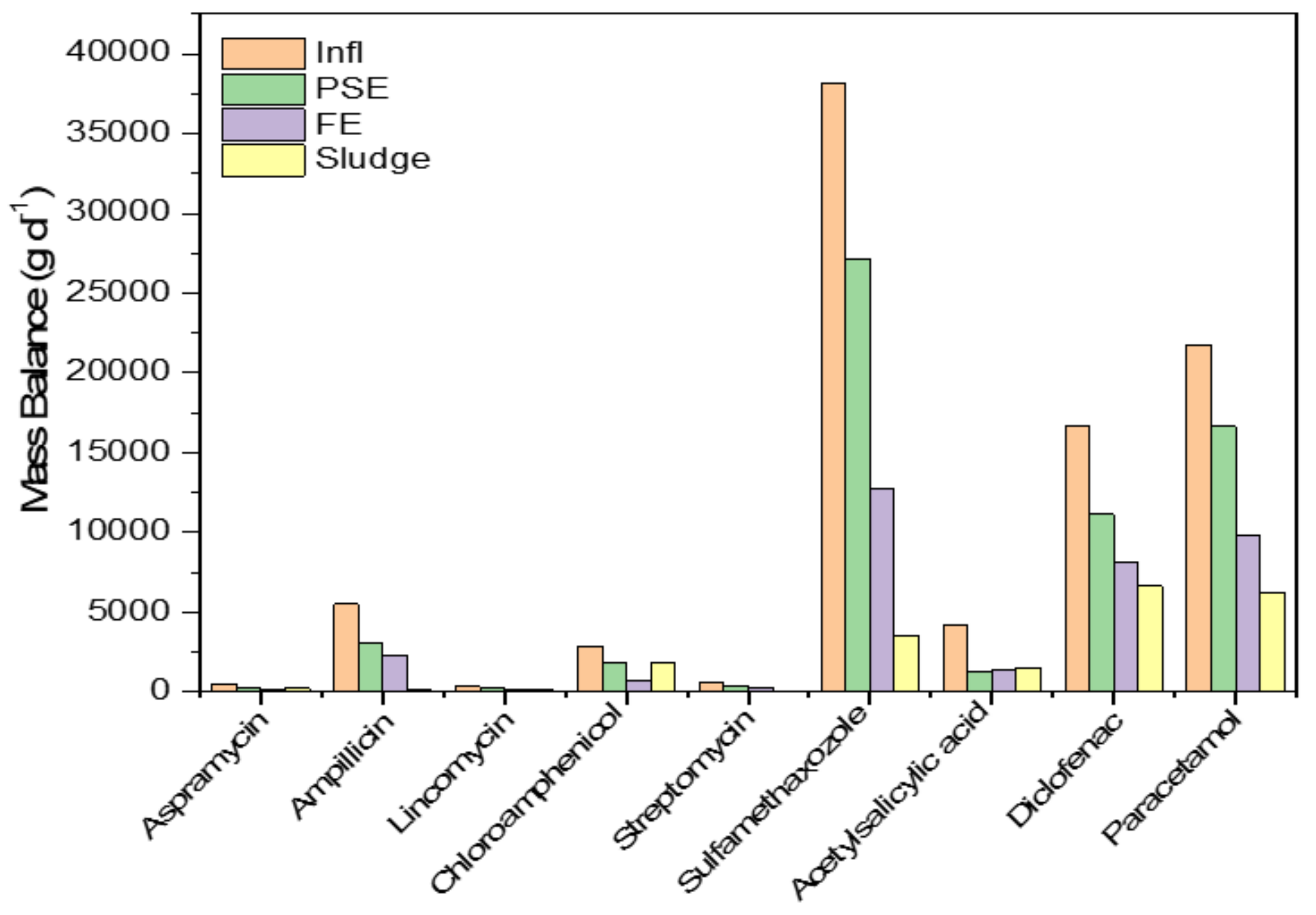

Figure 5

Mass balance of Pharmaceutical compounds in different stages of STP. 


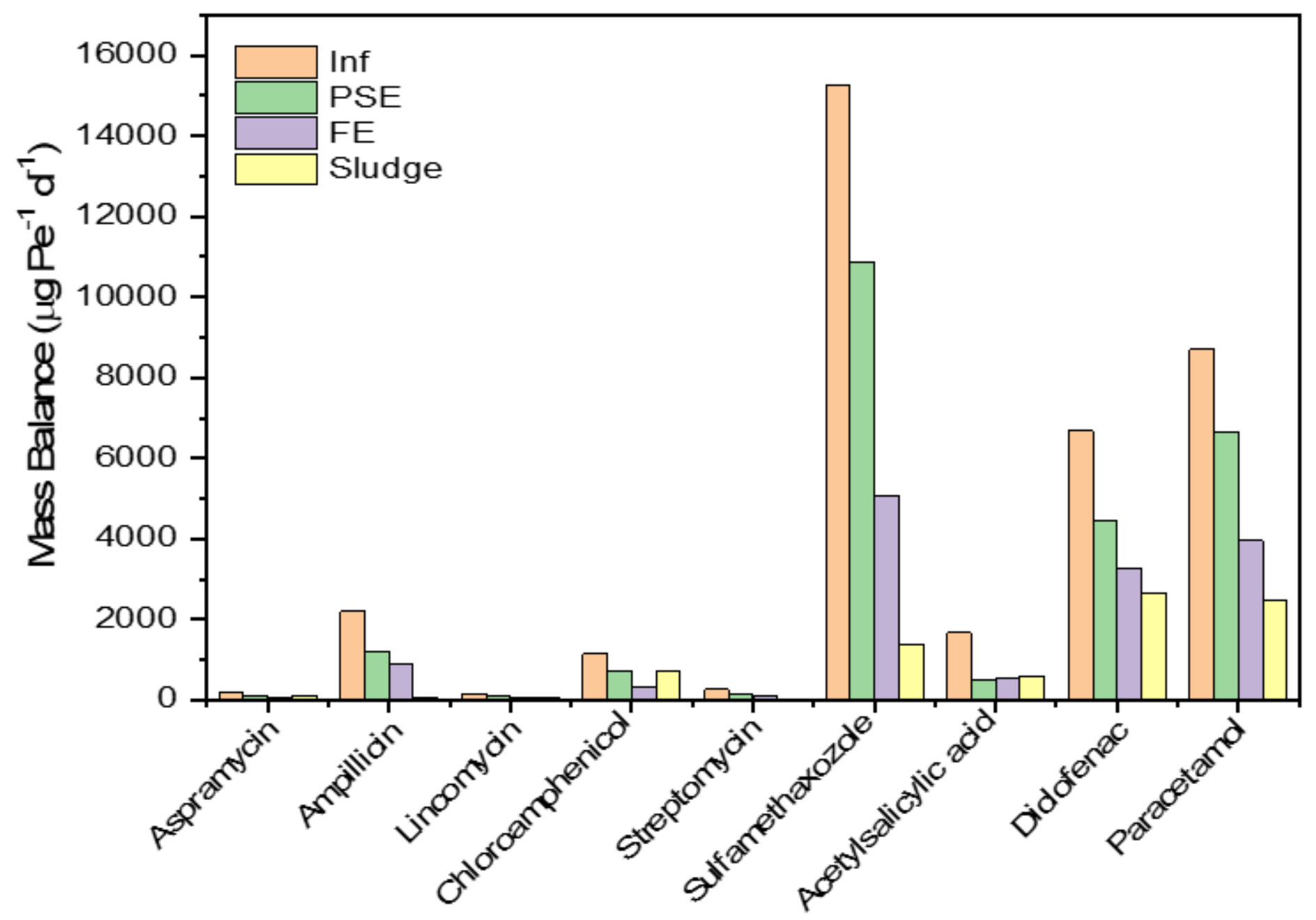

Figure 6

Personal Mass load of Pharmaceutical compounds in different stages of STP 


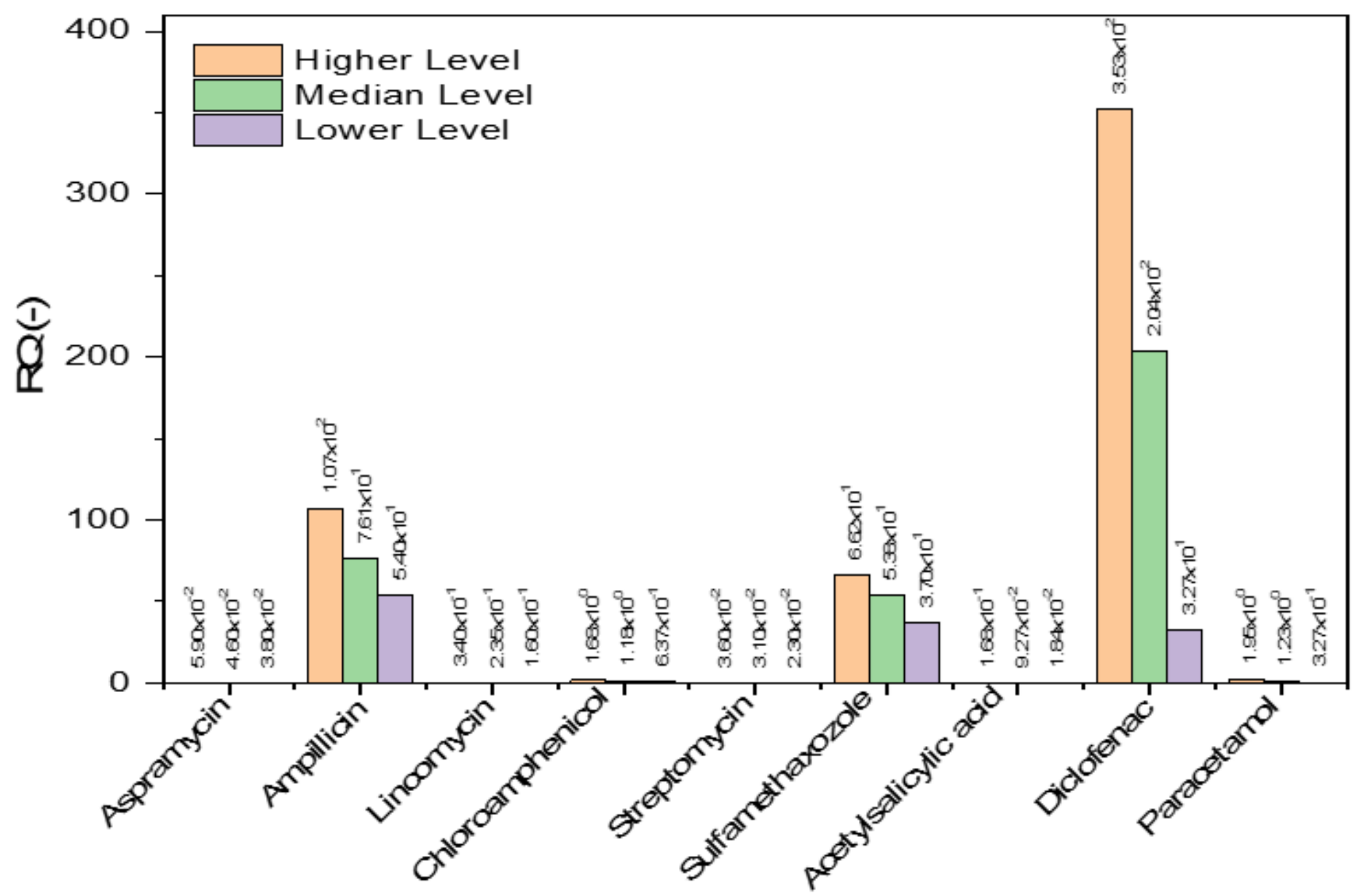

Figure 7

Risk quotients (RQs) of PhCs in STP effluents 